\title{
Tributes to Elisabet Helsing
}

I met Elisabet in the late 1980s when she was living in Copenhagen, heading up nutrition activities at WHO's regional office for Europe. At that time, I did not have much international nutrition experience so I said yes right away when she asked me to go to Mauritius and report on its efforts to prevent childhood malnutrition. In the month I spent there-January 1990--it became clear that I had landed in the middle of the nutrition transition, as we now call it. Type 2 diabetes and heart disease were increasing rapidly right along with persistent undernutrition in some segments of the population. With observations complete, I went to Copenhagen to work with Elisabet on my report. There, I got to see her in action, and impressive it was. She was right on top of every nutrition policy in each of the 30 or so countries then part of the region, knew all the key players in government and public health by name, and spoke on the phone to each of them in their own languages. I had never met anyone so stunningly beautiful, accomplished, forward thinking--and courageous. Not long after, she was diagnosed with Parkinson's-Mr. P., as she called it. She spent the rest of her years keeping Mr. P. at bay as best she could, while continuing her policy and breastfeeding work. She inspired me, all the way to the end. I could say more about the later times I saw her in New York or Oslo, but it's too heartbreaking. I took this photo at a meeting of the European Nutrition Society in Vienna in 1995, and that's how I want to remember her.

--Marion Nestle, Paulette Goddard Professor of Nutrition, Food Studies, and Public Health, Emerita, New York University 


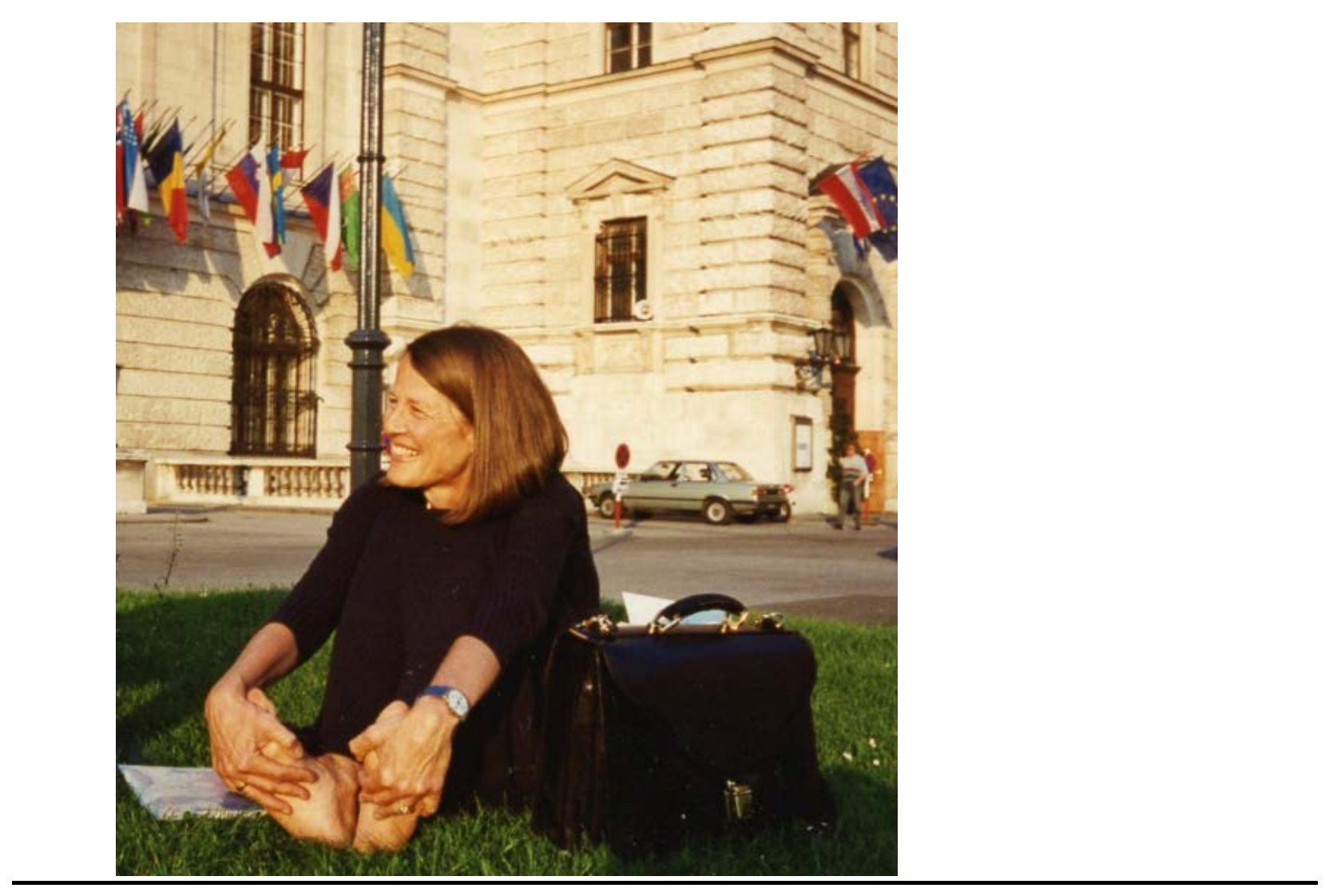

Elisabet Helsing was a unique critical person in the history of nutrition in Europe. I worked with her when I was involved in the G-7 in the transformation of the Soviet Union but also in her breast-feeding work early on and also in interactions on the critical work she did to try to push WHO Europe's activist agenda in nutrition. She came to Moscow several times to help me in some battles with the Russian parliament, organized some key European nutritionists to help with selected battles against old-fashioned Soviet thinking about protein, animal-source food and nutrition that ultimately led to a new poverty line and a living pension level for the poor. She was always there. She was a true nutrition advocate with passion, smarts and energy. She was also a role model who did not let her Parkinson's Disease impede her in her mission. I feel like she was the first person to push WHO Europe into a strong activist mode in pushing the member nations into policy advocacy. She has been followed by others until today, but she began this work.

\section{--Barry Popkin}

It was with great sadness we learnt about Elisabet's passing. Elisabet knew the importance of combining scientific knowledge with strategic political thinking, and topped that up with bravery and dogged determination. We always admired her courage and will to stand up for what is right. She was widely known as a spokeswoman against unethical marketing of breast-milk substitutes. This was a natural corollary of her fight for the human right of babies to adequate food which was breastmilk, and mothers' right to breastfeed. 
Elisabet graciously accepted the challenge of becoming the President of the 8th European Nutrition Conference to be held in Lillehammer, Norway in June 1999. It was hosted by the Norwegian Nutrition Society and organized together with FENS - the Federation of European Nutrition Societies. With her great international experience and contacts within the world of nutrition, Elisabet was a great asset in all aspects related to communication, nationally and towards Europe, and delightful to work with. As a continuation of her Conference responsibility, she followed the tradition and became President of FENS for the next 4 years, from 1999 to 2003.

We had the pleasure and honour to work with her in the secretariat of FENS during these years. She was determined to use her status as FENS President to work for change. Among other tasks, she drafted and introduced a set of Ethical Guidelines to regulate corporate sponsorship of FENS, to the dismay of some, including companies marketing breast-milk substitutes at the FENS conferences.

Elisabet was a remarkable woman and will be missed.

--Siri Damman, Norwegian Rainforest Foundation, Former Secretary of FENS

--Helle Margrethe Meltzer, Norwegian Institute of Public Health, Member of the Organising Committee of the 8th European Nutrition Conference

It is indeed sad to hear that our much-loved friend and cherished colleague Elisabet has passed away. She will always be remembered for her staunch support of human rights and justice for all mothers and babies, which was deeply reflected in all her work on the protection, promotion and support of breastfeeding.

Elisabet will be remembered for the many gifts she left us as a mentor, as a dogged challenger of those powers working to undermine mother and child supports, as an author contributing her breastfeeding texts to our global community, as a policy maker at WHO and the UN Standing Committee on Nutrition, and so much more.

I will never forget when we sat together in the front row of an SCN event with a dais of industry funded promoters of nutrient interventions who ended up cringing from her adamant statements about the critical protection provided by exclusive breastfeeding. It was Elisabet's passion, grace and intelligence to protect breastfeeding that set the stage.

I am enriched for having known her as a friend and a sister traveler in the work we both cherish.

--Elisabeth Sterken, INFACT Canada, IBFAN Global Council

En avskedshälsning till Elisabet Helsing

Dear Elisabet!

Do miss you so. But you are among us and with us. You have always stood upright in every battle for what unites us and so many around the world to protect, promote and support breastfeeding. Our roads have met so many times since the early 70s. You were our role model 
and inspiration when we formed Amningshjälpen in Sweden, and you were our role model and hero when you raised and defended breastfeeding among pediatricians who were misled by the baby food industry's messages. You paved the way for breastfeeding for the individual mother, in Norway, in the Nordic countries, in Europe, in the world.

I had the privilege of meeting you around the world in connection with international meetings with WHO, IBFAN, WABA, including my home in Uppsala and with you in Norway. Mr Parkinson had a tough opponent. You never let yourself be hindered by Mr. Parkinson in your work for breastfeeding - the difference was time - it took more time for you. We found a tool * that allowed you to experience some "alleviation", to collect your energy. I contacted you on breaks, at lunch, in the evening - all the small moments that took place, in connection with various conferences, meetings.

I had the privilege of being involved when you got the King's Merit Medal in gold, to be your reader in connection with your latest book, to be your friend. I wish you a well-deserved rest that holds all love, all warmth, all gratitude for everything you have been, done and accomplished.

I carry you with me in my heart, Your namesake, Elisabeth (Kylberg in Uppsala) *Tool=TTT=Trauma Tapping Treatment

I was sorry to hear of Elizabet's passing. I first met her in 1996, just after she had retired from her job as WHO Regional Nutrition Adviser for Europe, when we participated in an eventful BFHI assessment mission which took us to Poland, Armenia and Russia (including a memorable train journey from Saint Petersburg to Moscow). Her commitment to breastfeeding and the best interests of mothers and babies was inspiring to a newcomer like me, and continued to inspire me over the years. I also greatly admired the courage and dignity Elizabet displayed in coping with her long illness, while continuing to be a tireless advocate for breastfeeding and human rights. She will certainly be missed by the breastfeeding community.

--David Clark, UNICEF

I was truly sad to learn that Elisabet had passed away. I feel incredibly privileged to have worked with her and benefited from her exceptional inspiration, experience, knowledge, intelligence and sharp humour. She was so strong and merited, yet treated students like me as peers and was always supportive and encouraging. She was one of the best supervisors ever, and she will always be a role model to which I aspire.

Apart from everything that I have learnt about breastfeeding and nutrition policy, the two of us had such a great time on a boat trip that we took among some amazing islands off the coast of Viet Nam after the SCN session in Hanoi.

I am also grateful to her for having been breastfed myself, as my mother read her books in the early 70s which helped her succeed in this womanly art and endure the poor maternity 
protection conditions at the time. According to my mum, I was ever since a shamelessly healthy child.

My thoughts are with her family. I thank Graham who included me in the family and in the visiting schedule for close friends during the past year. I am so glad that I made it once to Oslo, and got to see her eyes spark with enthusiasm and campaigning spirit from hearing the latest WHA IYCF resolution gossip.

-- Kaia Engesveen

In 1975 I was wheeled into the delivery room at Köpings lasarett, Sweden. I brought two books: Elisabet Helsing's book on breastfeeding and Frederick Leboyer's book on natural delivery. Both books came to be very important to me as a young mother and nutritionist. Ten years later I went to a workshop on community nutrition that Elisabet and Arne Oshaug were organising in Hungary. A few of the other students became a part of the important network in public health nutrition that later grew strong in Europe and which I was honoured and happy to coordinate for more than fifteen years, with support from the European Commission. Elisabet started to feel the effects of her Parkinson in the early nineties, but I was fortunate to run a couple of summer schools with her in Lithuania and in Poland. I have always felt that she was an important person in my life as well as in my developing career. The night before I was reached by the news of her death, I gave a dinner speech referring to her. She was on my mind.

Thank you Elisabet for showing the courage to be yourself in an environment dominated by men. I will always remember you, and your name and photo are a part of my power-point presentation on breastfeeding at the lectures I provide every year to my students. Your book on breastfeeding that I later on was happy to translate to Swedish, is now used by my daughters and nieces and hopefully many other young women, who, like I once did, bring the new edition to the delivery room.

--Agneta Yngve, Chair professor at Uppsala university

If health-promoting and preventive measures are to have any effect on public health, it presupposes that the population accepts the measures. It's a banal statement, but no less true for that. Norway was early with a clearly formulated nutrition policy, with some very successful results. It was this that Elisabet Helsing wanted to bring to other parts of the world through her work at the WHO European Office. She was an educator with a nutritional scientific background who, with enthusiasm and colourful figures (drawn by herself!), managed to get steadfast but not always so enthusiastic health politicians to understand the close association between nutrition and health. And that political measures were complex but necessary. At the same time, she understood that all aspects of the nutrition subject were necessary if the policy were to have a credible basis. Around her, she built an international network that secured this foundation. I had the privilege of being drawn into parts of this work and experienced how Elisabet turned nutrition policy making into an exciting arena.

--Dag S Thelle, University of Oslo (emeritus) 
I only met Elisabet Helsing once, but she had a profound impact on the way I have perceived and have done health promotion during my career as teacher, lecturer and adult education facilitator. In the early 1980s, I was a post-secondary student doing my Advanced Level Home Economics course in Malta. Dr Helsing came to talk to the student body on diet and health, more specifically, on the importance of breastfeeding. Her messages were clear, yet imbued with a sense of urgency and passion. She also knew how to grip her audience. A particular instance I remember well is when she actually announced that men should also taste the breastmilk of their partners so they know what their babies are drinking. This intrigued me at the time...but one can also imagine the reaction of all the male students in the hall! It was a bold statement which left its mark on me, not only with respect to promoting breastfeeding (as relevant) among the many teachers I have interacted with over the years, but also on the value of clear, logical and curiosity-generating health communication for behaviour change. Thank you, Dr. Elisabet for being part of my story.

--Suzanne Piscopo 